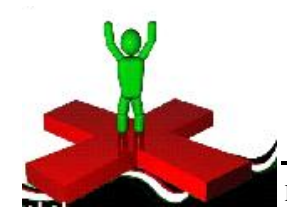

International Journal of Medical Sciences

DOI : 10.15740/HAS/IJMS/7.1and2/38-42 Volume 7|Issue 1\&2|October, 2014|38-42

e ISSN-0976-7932 | Visit us - www.researchjournal.co.in

RESEARCH PAPER

\title{
Mental health of undergraduate students and its influencing factors
}

\section{JAYA BANGALE AND VISHALA PATNAM}

See end of the paper for authors' affiliation

Correspondence to : JAYA BANGALE Department of Human Development and Family Studies, College of Home Science, Vasantrao Naik Marathwada Krishi

Vidyapeeth, PRABHANI (M.S.) INDIA

Email: bangalej@gmail.com

Key Words :

Mental health, Socio economic status, Dimensions of mental health status
ABSTRACT : Two hundred undergraduate students between the age group of 18-23 yrs were selected from randomly chosen five colleges of Parbhani town of Marathwada region, Maharashtra State between the age group of 18-23 yrs by simple random sampling method with an intention to have the youth of diverse background in the sample. The data pertaining to the study were collected by personally interviewing the sample undergraduate students based on open ended interview schedule and by administering on them Mental Health Inventory, Self-Esteem Inventory and Socio-Economic Status Scale. No significant differences were recorded with respect to the mental health status of the students based on their socio-economic status and gender. With respect to the various dimensions of mental health of the sample students and its magnitude based on their SES, significantly a higher percentage of the male students in low SES families assessed to have good group oriented attitude than their counterparts female students, while it was vice-versa with regard to the poor environmental mastery. On the other hand, in middle SES group, significantly a higher percentage of the female students were assessed to have good integration of personality, fair positive self-evaluation and group oriented attitude than their counterparts male students. However, significantly a higher percentage of the male students were recorded to have good group oriented attitude and fair autonomy as compared to the female students. Hence, there is a great need to provide strong and positive supportive social network of family, peers, lecturers and neighbourers to youth for helping them to have good mental health in addition to training them on relaxation strategies and techniques for combating with stress to empower them so as to lead a quality life.

How to cite this paper : Bangale, Jaya and Patnam, Vishala (2014). Mental health of undergraduate students and its influencing factors. Internat. J. Med. Sci., 7(1 \& 2) : 38-42. 